Cite as: Sheaves M, Johnston R, Connolly RM, Baker R (2012) Importance of estuarine mangroves to juvenile banana prawns. Estuarine, Coastal and Shelf Science 114:208-219

\title{
Importance of Estuarine Mangroves to Juvenile Banana Prawns
}

\author{
Marcus Sheaves, Ross Johnston, Rod M. Connolly, Ronald Baker
}

Marcus Sheaves \& Ross Johnston \& Ronald Baker: Estuary and Tidal Wetland Ecosystems Research Group, School of Marine and Tropical Biology, James Cook University, Townsville, Queensland 4811, Australia

Rod M Connolly: Australian Rivers Institute - Coast and Estuaries, and School of Environment, Griffith University, Gold Coast, Queensland 4222, Australia

\section{Abstract}

Offshore catches of banana prawns, Penaeus merguiensis, are correlated with the extent of mangrove forests. However, recent evaluation has questioned whether the apparent relationship between juvenile penaeids and mangroves reflects specific utilisation of mangroves or just the use of shallow, organically rich, muddy habitats. We investigated this by focussing on juvenile $P$. merguiensis within 30 mangrove estuaries spanning $650 \mathrm{~km}$ of the coast of north-eastern Australia. We investigated a range of hierarchically clustered spatial scales and within-estuary spatial resolutions, as well as variables representing a variety of estuary structural factors, anthropogenic impacts, and particular hypotheses about the ways in which mangroves could influence $P$. merguiensis catch per unit effort (CPUE). Estuary to estuary differences, rather than climatic zone or the proximity of other estuaries, was the major large scale spatial influence on CPUE. At the amongestuaries scale mangrove extent appeared to influence CPUE but was extensively confounded with the effects of two non-mangrove variables; intertidal extent and substrate type. The fact that 3 alternative measures of the importance of connectivity with mangrove forests were not influential points to the importance of the non-mangrove variables rather than mangrove extent. At the withinestuary scale $P$. merguiensis CPUE was correlated with the extent of shallow water but not with mangrove variables. The spatial and temporal extent of sampling support a strong conclusion that factors associated with mangroves alone do not drive abundances of juvenile prawns. Nevertheless mangroves are one of the dominant habitats in the complex of interacting habitats that make up tropical estuaries inhabited by juvenile penaeids comprise a complex of interacting habitats, so causal relationships are complex and difficult to define unambiguously. 


\section{Introduction}

Many penaeid species have strong associations with particular coastal habitat features. Peak catches often correlate with the proximity of major wetlands (Rozas \& Minello 1998, Zimmerman et al. 2000), river mouths (Dalzell et al. 1996), seagrass beds (Coles et al. 1993), or mangroves (Subramaniam 1990, Manson et al. 2005), reflecting the high nursery value of these habitats (Sheaves et al. 2007a, Minello et al. 2008). Not only are coastal wetlands vitally important to penaeids, but penaeids themselves are critical links in the complex food webs supporting biological function in these ecosystems (Abrantes \& Sheaves 2009a). Penaeids occupy low trophic levels feeding on phytodetritus (Abrantes \& Sheaves 2009b) and micro invertebrates (Kieckbusch et al. 2004, Karani et al. 2005), and are in turn prey for important predatory fish (Robertson \& Duke 1990, Salini et al. 1998). Additionally, many penaeids have life-cycle migrations in which estuarine juveniles are the biological vehicles for translocating nutrient subsidies across ecosystem boundaries (Deegan 1993, Sheaves 2009). Consequently, the health and integrity of coastal nurseries, and the manner in which penaeids utilise them, are critical to both the functioning of coastal ecosystems and to the offshore fisheries they support (Barbier \& Strand 1997, de Graaf \& Xuan 1998).

The banana prawn, Penaeus merguiensis, is an important target for commercial and subsistence fisheries from Pakistan east to Taiwan and Indonesia, and south to Papua New Guinea and tropical Australia (Holthuis 1980). P. merguiensis exhibits a typical penaeid life cycle (Dall et al. 1990), with adults occupying and spawning in near- and off-shore waters (Crocos \& Kerr 1983, Rothlisberg et al. 1985), and larvae migrating to estuarine nurseries (Rothlisberg \& Jackson 1987).

Mangroves are the primary nurseries of $P$. merguiensis (Staples et al. 1985, Staples \& Vance 1985, Primavera 1998), and offshore catches often correlate with the presence of estuarine and coastal mangroves (Manson et al. 2005, Meynecke et al. 2008). However, our understanding of the exact relationship between $P$. merguiensis and mangroves is patchy, incomplete and restricted in its breadth of spatial representation. Relationships based on offshore catches are often difficult to interpret because of the coarse resolution of available data. For example, the data used for large scale analyses of Manson et al. (2005) and Meynecke et al. (2008) were reported on a 30 nautical mile grid ( $1 / 2$ degrees of latitude). Determining the relationship between $P$. merguiensis and mangroves is further complicated by correlations with other factors (e.g. the presence of river mouths (Dalzell et al. 1996)), analytical difficulties (Lee 2004), considerable spatio-temporal variability, and uncertainty about migration patterns (Loneragan et al. 2005). For instance, on Australia's northwest shelf the offshore fishery for the closely related $P$. indicus is hundreds of kilometres from their mangrove nursery grounds (Kenyon et al. 2004). Such issues, and the realisation that environmental variation that regulates offshore prawn catches actually acts on early life-history stages during residence in estuary nursery areas (Staples \& Vance 1986, Vance et al. 1998), have prompted calls for studies that address the relationship between $P$. merguiensis and mangroves more directly by focusing on the mangrove systems themselves (Manson et al. 2005). This need is strengthened by analysis suggesting that factors such as tidal amplitude may have a stronger influence on penaeid abundance than the extent of mangroves themselves (Ahmad Adnan et al. 2002, Lee 2004).

While a number of studies have investigated $P$. merguiensis at smaller, within-nursery scales, most have only considered a limited number of estuaries in just a few geographical areas, or used large scale sampling gear such as beam trawls (e.g. Staples 1979) that focus on the main body of the 
estuary and do not allow the effect of small-scale habitat differences to be investigated.

Consequently, we have incomplete understanding of the spatial and temporal consistency of utilisation of estuarine nurseries by juvenile $P$. merguiensis, the relationship of $P$. merguiensis to small-scale habitat variations, and thus of the precise relationship of $P$. merguiensis with mangroves. We know that $P$. merguiensis favours areas of estuaries with muddy rather than sandy substrates (Vance et al. 1990, Kenyon et al. 2004), shallow rather than deep banks (Johnston \& Sheaves 2007), and turbid over clear areas (Johnston et al. 2007). Furthermore, the few studies that have sampled within mangrove forests have shown that $P$. merguiensis juveniles occur there at high tide (Vance et al. 1996, 2002). However, it is unclear if this reflects specific utilisation of mangroves or just the use of shallow, organically rich, muddy habitats (Lee 2004) in tropical estuaries that are almost invariably mangrove lined.

Given the uncertainty about the relationship of penaeids to mangroves raised by Lee (2004) and the lack of estuary scale evaluation identified by Manson et al. (2005) it is relevant to focus on the relationship between $P$. merguiensis and mangroves at the level of estuarine nursery grounds themselves. If the established correlations between offshore fisheries catches and estuarine wetland nursery habitat characteristics (Manson et al. 2005, Meynecke et al. 2008) reflect important population regulating processes acting on juvenile life stages, then juvenile populations should respond to differences in the relative extent of mangroves among estuaries, and specific mangrove habitat characteristics within the estuaries themselves. We sampled juvenile $P$. merguiensis (1$25 \mathrm{~mm}$ carapace length) extensively along the lengths of 30 mangrove estuaries spanning $650 \mathrm{~km}$ of northeast coastline of north-eastern Australia, incorporating a range of hierarchically clustered spatial scales and within-estuary levels of spatial resolution. The primary aims were (i) to determine the spatial and temporal consistency of utilisation of estuarine nurseries by juvenile $P$. merguiensis, and (ii) to investigate the among- and within-estuary relationships of $P$. merguiensis juveniles to spatial and biological factors (especially mangroves) and anthropogenic factors.

\section{Methods}

\section{Sampling}

The study is part of a broader investigation examining spatial and temporal dynamics of estuarine nekton among a large number of tropical estuaries in north-eastern Queensland, Australia, with previous work concentrating on juvenile fish. The study comprises two components, and site maps, and detailed descriptions of the sampling designs can be found in the papers describing patterns in the fish assemblage; Sheaves and Johnston $(2009,2010)$ and Sheaves et al. (2010).

In the "among-estuaries" component, 21 estuaries spanning $650 \mathrm{~km}$ of the coastline of northeast Australia, from Saltwater Creek in Trinity Bay, to Constant Creek in the Hillsborough Channel, were sampled over 4 consecutive spring tidal cycles during the late dry season between August and October 2007 (Sheaves \& Johnston 2009). The number of estuaries included prohibited the repeated sampling of each estuary through time; however 5 were repeat-sampled to evaluate temporal consistency of prawn densities. The sampling design allowed for spatial dynamics to be examined across a range of hierarchically clustered spatial scales. The 21 estuaries spanned 3 climatic zones (northern wet tropics, dry tropics, and southern wet tropics), comprising 7 regions (discrete sections of coast or coastal waterways separated by headlands or capes), with $\mathbf{3}$ estuaries per region. Each estuary was divided into reaches (lower, mid, and upper), with $\mathbf{3}$ sites per reach 
(Sheaves \& Johnston 2009). 10 random replicate samples were collected per site, to ensure that catch data were representative of the sites.

The "within-estuary" component focussed on the dry tropics, the region with the highest abundance and occurrence of $P$. merguiensis in the among-estuaries study. Nine small ( $<8 \mathrm{~km}$ navigable length) natural estuaries were sampled. These spanned $225 \mathrm{~km}$ of the dry tropics coast centred on Townsville, from Insulator Creek in the north, to Hell Hole Creek in the south (Sheaves \& Johnston 2010). The estuaries were sampled monthly to bi-monthly between November 2007 and January 2009 (Sheaves et al. 2010). Flooding during Jan/Feb 2008 and Jan 2009 prevented sampling at some sites (see Table 1 in Sheaves et al. 2010). Small estuaries were chosen for the within-estuary study so that sampling could effectively cover the entire estuary and so prevent any within-estuary migrations from confounding apparent temporal trends. Two artificial estuaries included in the study of Sheaves et al. (2010) were excluded from the present study since penaeid prawns rarely occurred in samples from those systems. Estuaries were divided into reaches (lower and upper for all, with the addition of mid for the larger estuaries), with initially 90 , and subsequently 45 samples distributed evenly among reaches within each estuary on each sampling occasion (Sheaves \& Johnston 2010).

All samples were collected with a $2.4 \mathrm{~m}$ radius monofilament draw-string cast net with $5 \mathrm{~mm}$ mesh. This approach allowed much more specific focus on individual habitat types than previous studies using gear such as beam trawls (Staples 1979). The same operator collected all samples throughout both components of the study, from a $4.3 \mathrm{~m}$ boat fitted with an electric motor to minimise disturbance of sampling areas prior to net deployment, following the protocols set out by Sheaves et al. (2007b). Sampling was conducted during the lower half of the tides when mangrove forests were drained. All samples were collected along the banks of the estuaries since these habitats contain the bulk of small nekton, including penaeid prawns, during the lower parts of the tidal cycle (Johnston \& Sheaves 2007, Johnston \& Sheaves 2008). This sampling design resulted in a total of 2030 individual replicate cast net samples for the among-estuaries study, and 3469 replicate samples for the withinestuary study.

\section{Statistical analyses.}

Among-estuaries component: $P$. merguiensis among-estuaries catch data were analysed using univariate Classification and Regression trees (CARTs) (De'ath \& Fabricius 2000). Site was the focal sampling unit so the 10 replicate nets per site were used to calculate the dependent variable, mean CPUE per net for each site. There were zeros in the final data set so the CPUE data were scaled to means per 100 nets to allow a $\ln (x+1)$ transformation (which produced the most symmetrical distribution of residuals) to be used without the addition of 1 unit biasing the data where mean catches were low. As well as the 4 spatial variables (Zone, Region, Estuary, Reach), 21 non-spatial predictors were defined at the estuary level; 11 estuary structure variables, 5 mangrove variables, and 5 impact variables (Table 1). These predictors were constructed to allow evaluation of the importance of specific potentially influential factors and processes (Table 1). Selection of the final CART model was conducted using 10-fold cross validation, with the 1-SE tree (the smallest tree with cross validation error within $1 \mathrm{SE}$ of that of the tree with the minimum cross validation error) selected as the final tree model, a procedure that produces valid, biologically interpretable trees (Breiman et al. 1984, De'ath \& Fabricius 2000). The impact of each variable on model structure was evaluated by its occurrence in the final 1-SE tree. Additionally, the "relative importance" of variables 
was assessed to ensure variables that had high overall importance, but were not the best predictors for particular splits, were not overlooked. Importance is determined by using each variable at each branching of the final tree, with the best overall classifier given a relative importance of $100 \%$.

Within-estuary component. $P$. merguiensis within-estuary study data were again analysed using CARTs. The dependent variable was mean CPUE per 100 nets to allow a log $(x+1)$ transformation, which produced the most symmetrical distribution of residuals. This analysis focussed at small-scale (net-to-net level) differences. As well as Trip, Location and Reach, 8 predictor variables (Table 2) recorded for each net sample were used to investigate small scale correlates of $P$. merguiensis distribution.

\section{Results}

Among-estuaries component. $P$. merguiensis juveniles were present in all 21 mangrove estuaries. The CART model (43\% variability explained) was dominated by the spatial factors Estuary and Reach (Fig. 1). Estuary-to-estuary spatial differences form 4 of the 6 splits in the final model and had the highest relative importance. Notably neither Zone nor Bay was an influential predictor, and, all major estuary groupings are comprised of estuaries from a mixture of Zones and Bays. Reach formed 2 splits in the CART model but overall had a low relative importance ( $26 \%$ that of Estuary). It had its principal effect in lower CPUE estuaries, where CPUE values were higher downstream than in mid and upstream reaches (Fig. 1a). Although non-spatial factors did not feature in the CART model, Intertidal Extent (intertidal area relative to sub-tidal area) and Mangrove Extent (mangrove area relative to sub-tidal area) had the second (65\%) and third (60\%) highest relative importances respectively (Fig. 1b), indicating that, although not in the predictor set for the final CART model, they possessed considerable explanatory power and potentially explained much of the spatial difference. Other predictors had relative importances below $50 \%$. We examined the influence of structural and biological variables in more detail by using CART analysis again but this time omitting spatial variables. The best CART tree had a primary split on Mangrove Extent (Fig. 2a) and there were very high overall relative importances for both Intertidal Extent and Mangrove Extent (Fig. 2b), for a tree that explained almost as much variability (41\%) as the one that included spatial factors. Moreover, both Mangrove Extent and Intertidal Extent have clear positive correlations with $P$. merguiensis CPUE (Fig. 3). Sediment Type also had high relative importance between those of Intertidal Extent and Mangrove Extent (Fig. 2b), indicating that this could also be an influential factor.

Repeat samples from individual estuaries (Armstrong Ck., Baratta Ck., Boyd's Ck., Meunga Ck., Ross R.) showed very similar CPUEs indicating consistency within sites over the sampling period (Fig. 3).

Within-estuary component. Juvenile $P$. merguiensis were present throughout the study, with even the smallest size classes ( $<5 \mathrm{~mm}$ carapace length) found in most estuaries in all months sampled. When within-estuary factors are considered across 9 estuaries over time, estuary level temporal and spatial explanatory variables dominate the CART (Fig. 4a). P. merguiensis juveniles were present in all mangrove estuaries throughout the year but there was a strong primary temporal split with highest CPUEs in the post wet season (March to May), and lower catches in the dry, prewet and wet seasons, although the actual details of the temporal pattern were quite variable (Fig. 5). Mud and Sandfly Cks had the highest CPUEs in all seasons, while Cocoa Ck was in the high CPUE group in the post-wet but not in the dry, pre-wet or wet seasons. The opposite was true of Hell Hole $\mathrm{Ck}$, which was notable for having low P. merguiensis CPUEs in the post-wet compared to other 
seasons (Fig. 5f). There were substantial differences in CPUEs among the 4 primary tree groups, with estimates for the high CPUE post-wet estuaries more than 5 times greater than for low CPUE postwet season estuaries and all estuaries in the dry, pre-wet and wet seasons (Fig. 4b).

Despite the domination of the CART by temporal and spatial factors, a number of site-specific factors (substrate, hydrodynamics, bank angle, dominant vegetation) were important within particular spatio-temporal combinations (Fig. 4a). Notably, dominant vegetation type (the only vegetation related explanatory variable to be influential) only played a minor role in explaining small differences in restricted parts of the data set and had only moderate relative importance (59\%) (Fig. 4c). In contrast, bank angle was influential in many parts of the tree, with high CPUEs invariable associated with lower bank angles and thus more extensive shallow water edges. Bank angle also had the second highest predictor relative importance (93\%) after location, indicating strong influence in explaining the pattern of variability. When the data are considered trip by trip, bank angle is again very influential; over the 9 trips bank angle formed the second most primary tree splits, equal most total splits and second most occurrences in the list of variables with relative importance $>50 \%$ (Table 3).

CPUE was highest for most estuaries during the post wet (March - May) (Figs. 4a, 5a-i), with catches much lower through the rest of the year. This was not reflected in the pattern of change of prawn size, however, since the relationship between $P$. merguiensis CPUE and mean biomass per $P$. merguiensis varied substantially among sites (data not shown), and there was no clear negative relationship that would be expected if high CPUEs were driven by high numbers of small individuals.

\section{Discussion}

\section{Spatio-temporal consistency of utilisation of estuarine nurseries}

In contrast to what might be expected there were no indications of similarities in CPUE due to proximity (i.e. estuaries in the same Bay) or climatic zone. Rather the overriding scale of spatial variation in $P$. merguiensis CPUE was at the estuary to estuary level. This indicates that, as with fish (Sheaves 2006, Sheaves \& Johnston 2009), the particular characteristics of individual estuaries are more important than large scale physical variation among regions in determining patterns of distribution and abundance of $P$. merguiensis, and that within-estuary factors need to be investigated to understand the drivers of spatial patterns.

Within-estuary analysis showed that, although $P$. merguiensis catches tended to peak in the post wet season, the pattern was quite variable among estuaries. This matches with estuaries of Australia's Gulf of Carpentaria (GoC), where the majority of $P$. merguiensis research has been conducted, that show peak abundances varying among estuaries (Staples 1979). The relationship between $P$. merguiensis CPUE and mean biomass per $P$. merguiensis varied substantially among sites, with the lack of consistent negative relationships between CPUE and mean biomass per prawn. This inconsistent relationship is not surprising given a suite of studies from the GoC that show considerable spatio-temporal variation in recruitment (Staples et al. 1995), abundance (Staples 1979, Vance et al. 1998) and mean carapace length (Staples \& Vance 1987) of juvenile $P$. merguiensis. Consequently, the variable patterns in CPUE and its relationship with mean biomass could reflect inconsistent timing and/or success of recruitment among estuaries, or differences in 
the period of residence, growth and mortality rates, and/or timing of emigration among estuaries. For instance, changes in size of $P$. merguiensis in the GoC are influenced both by changes in emigration triggered by rainfall variation (Vance et al. 1998) and by the presence or absence of overwintering individuals (Staples \& Vance 1987). Inconsistency in recruitment, period of residence, growth, mortality or timing of emigration among estuaries could mask or add considerable noise to relationships between CPUE and the explanatory variables.

\section{Among- and within-estuary relationships to predictor variables}

The among-estuaries CART model structure was based entirely on spatial factors, with the focus of variation at the among-estuaries level indicating that key ecological processes operate at that scale (Holling 1992, Levin 1992, Hamid et al. 1999). However, a number of explanatory variables had strong predictive power in explaining the among-estuaries CART model structure; they had high relative importances in the model and became dominant explanatory factors when the spatial variables were excluded.

Mangrove Extent (mangrove area relative to sub-tidal area) was an important predictor of differences in $P$. merguiensis CPUE among estuaries, while other estuary structure, vegetation and impact variables (Table 1) were not. This accords with studies showing correlations between offshore catches of $P$. merguiensis and mangrove area (Manson et al. 2005, Meynecke et al. 2008), and is consistent with the idea that mangroves are key nursery grounds for $P$. merguiensis (Staples et al. 1985, Staples \& Vance 1985, Primavera 1998). However, Intertidal Extent and Substrate Type were also strong predictors, which aligns with the results of Lee (2004), who suggested that factors that are correlated with the occurrence of mangroves may actually exert the primary influence on penaeid abundance. More importantly, this result and the results of previous studies (e.g. Lee 2004, Manson et al. 2005) emphasise the difficulty of determining the importance of mangroves to penaeids like $P$. merguiensis; mangroves are a consistent feature of intertidal margins of tropical estuaries (Duke 1992), so the effect of mangroves are confounded with a range of other intertidal variables. Some clarification comes from stable isotope studies, a number of which have concluded that mangroves in northern Australia provide limited nutritional support to $P$. merguiensis juveniles (e.g. Loneragan et al. 1997, Sheaves et al. 2007a, Abrantes \& Sheaves 2009c) (but see Chong et al. (2001) for an alternative view for Malaysian mangroves). If mangroves themselves are important to juvenile $P$. merguiensis it appears likely to be for a reason other than nutritional support. A second line of evidence comes from $P$. merguiensis catch data from the Pacific, where catches are associated with large estuarine mangrove systems rather than coastal mangroves (Dalzell et al. 1996). This implies that it is estuaries rather than mangroves that are important to $P$. merguiensis, although it may simply be that estuaries harbour the largest areas of mangrove.

Considering the assumptions underpinning the among-estuaries mangrove predictors that were not influential in the among-estuaries model (Table 1) sheds light on the mechanisms underlying potential relationships to mangroves. In particular, Mangrove-Water Interface, Mangrove Edge Extent and Mangrove Forest Access ( 3 alternative measures of the importance of connectivity with the mangrove forests) all had very low predictive power in both the CART model including all predictors (Fig. 1b) and the model with only non-spatial variables (Fig. 2b). This indicates that the amount of access to mangroves in an estuary is not a critical factor determining $P$. merguiensis 
distribution at the estuary to estuary scale, so a variable such as Intertidal Area or Substrate Type is more likely to be the actual determinant of $P$. merguiensis distribution than Mangrove Extent.

When viewed at a within-estuary scale $P$. merguiensis CPUE did not correlate with any of the mangrove variables (Table 2), rather, high CPUEs correlated with low bank angles, used as a proxy for the occurrence of shallow water through extended periods of the tidal cycle. This aligns with the importance of Intertidal Area in the among estuary scale study, reinforcing the idea that $P$. merguiensis CPUE it is more likely to be determined by the presence of extensive areas of shallow water than the presence of mangroves per se (Lee 2004), with prawns probably utilising a range of resources from different parts of the mosaic of habitats that comprise tropical estuaries (Sheaves 2005, 2009).

\section{Conclusion}

The extensive correlations between the presence of mangroves and other features of tropical estuaries make definitive determination of the importance of mangroves to $P$. merguiensis, and other penaeids, extremely challenging. If juvenile $P$. merguiensis use tropical estuaries for reasons not directly related to the presence or extent of mangroves, why do they occur predominantly in mangrove systems? The classical concept is that mangroves provide juvenile nekton with food, low numbers of predators and/or structural refuge from predation (Robertson \& Blaber 1992, Laesggard \& Johnson 2001). Nutritional explanations are attractive but difficult to validate. The complex habitat mosaics that comprise tropical estuaries (Sheaves 2009) do provide rich and diverse sources of nutrients to juvenile nekton (Bouillon et al. 2007, Abrantes \& Sheaves 2008, Abrantes \& Sheaves 2010), but there seems to be no research that would explain why $P$. merguiensis preferentially use mangrove habitats for nutrient acquisition if it is not to access mangrove carbon. Similarly, the idea that mangrove systems have low numbers of nekton predators (Blaber 1980) has been shown not to apply to tropical Australian estuaries, where both specialist shallow water predators (Baker \& Sheaves 2006) and small predatory nekton (Baker \& Sheaves 2009) are abundant. The proposition that estuaries provide a refuge from predation appears to have more substance. $P$. merguiensis responds strongly to turbidity, showing much higher abundances in turbid compared to adjacent less turbid water (Johnston et al. 2007), although there are a number of possible explanations for this other than refuge from predation.

Definitive understanding of the actual importance of mangroves to $P$. merguiensis, and other penaeids, will require determination of the specific benefits gained from using particular estuarine habitats. It is possible that the complexity of the interaction might make unambiguous understanding impossible. Whatever the situation, the apparent lack of direct relationship between $P$. merguiensis and mangroves should not be taken as an indication that mangroves are not important. On the contrary, mangroves play critical roles in stabilising shorelines and facilitating the accumulation of organic peat (Gedan et al. 2011), so the very presence of mangroves is critical to the development and maintenance of the muddy, shallow water habitats that $P$. merguiensis rely on. Moreover, mangroves are critical components of the complex ecosystem mosaic supporting nekton that spend part of their life histories in tropical estuaries (Sheaves 2009). The importance of maintaining the integrity of this mosaic is emphasised by our increasing understanding of connectivity (Sheaves 2005, Nagelkerken 2007) that covers the spectrum of biological processes 
ranging from enabling complex trophic dynamics (Bouillon et al. 2007, Bouillon et al. 2008) to critical support for offshore ecosystem resilience (Mumby et al. 2004). 
Figure Captions

Figure 1: CART analysis of $P$. merguiensis CPUE for the "among estuaries" data with all predictor variables included. (a) 6 leaf CART tree. Capitalised titles indicate the factor forming each split, text next to the branches indicates the composition of each branch, bar graphs below each terminal branch show the distribution of log transformed CPUE, numbers below the bar graphs indicate the mean response for each branch, numbers in brackets indicate numbers of sites (groups of 10 replicate nets) represented by each node. (b) Relative importance of the variables providing the best overall classification for the CART tree.

Figure 2: CART analysis of $P$. merguiensis CPUE for the "among estuaries" data with spatial predictor variables excluded. (a) 5 leaf CART tree. Capitalised titles indicate the factor forming each split, text above branch nodes indicates the values defining each branch, bar graphs below each terminal branch show the distribution of CPUE, numbers below the bar graphs indicate the mean response for each branch, numbers in brackets indicate sample sizes at each node. (b) Relative importance of the variables providing the best overall classification for the CART tree.

Figure 3: Relationship between P. merguiensis CPUE and (a) Mangrove Extent, and (b) Intertidal Extent for the "among estuaries" data. CPUE data are log +1 transformed means (and SE) across sites and reaches. Because this figure focuses on overall relationships rather than estuary-to-estuary comparisons, individual estuaries are not identified; except in the case of those that were repeat sampled. These are identified to allow evaluation of consistency of the repeat samples. White symbols indicate repeat samples: squares $=$ Armstrong $\mathrm{Ck}$, triangle up $=$ Barratta Ck., diamonds $=$ Boyd's Ck., triangles down $=$ Meunga Ck., diamonds $=$ Ross R.

Figure 4: CART analysis of $P$. merguiensis CPUE for the "within estuary" data. (a) 35 leaf CART tree. Symbols indicate the factor forming each split, for uppermost splits text above branches indicates the composition of each branch, for lower splits only one split value is indicated above the branch or via arrows from labels. (b) Estimated CPUE for the 4 primary tree groups. (c) Relative importance of the variables providing the best overall classification for the CART tree.

Figure 5: Details of $P$. merguiensis CPUEs over time for the "within estuary" data. The grey box indicates the post wet season period (March to May).

Figure 6: Relationship between P. merguiensis mean CPUEs and mean biomass for the "within estuary" data. 
Tables

Table 1: Explanatory variables for 21 estuaries in "among-estuaries" analysis

\begin{tabular}{|c|c|c|c|}
\hline & Name & Description & Purpose \\
\hline \multirow{4}{*}{$\begin{array}{l}\text { Spatial } \\
\text { variables }\end{array}$} & Estuary & Estuary name & \multirow{4}{*}{$\begin{array}{l}\text { Allow determination of critical spatial } \\
\text { scale at which variability is focussed }\end{array}$} \\
\hline & Zone & $\begin{array}{l}\text { northern wet, dry, southern } \\
\text { wet tropics }\end{array}$ & \\
\hline & Region & $\begin{array}{l}\text { discrete sections of coast } \\
\text { separated by headlands }\end{array}$ & \\
\hline & Reach & lower, mid, upper & \\
\hline \multirow{11}{*}{$\begin{array}{l}\text { Estuary } \\
\text { Structure } \\
\text { variables }\end{array}$} & Estuary classification & \multirow{9}{*}{$\begin{array}{l}\text { defined Tables } 2 \text { \& } 3 \\
\text { Sheaves \& Johnston (2009) }\end{array}$} & \multirow{10}{*}{$\begin{array}{l}\text { Allow assessment of the } \\
\text { geomorphological form of the estuary }\end{array}$} \\
\hline & Entrance structure & & \\
\hline & Influence at entrance & & \\
\hline & Tidal range & & \\
\hline & Estuary length & & \\
\hline & Sinuosity & & \\
\hline & Subtidal area & & \\
\hline & Intertidal area & & \\
\hline & Sediment type & & \\
\hline & Shape of system & $\begin{array}{l}\text { Intertidal perimeter } \\
(\mathrm{m}) / \text { Subtidal Area }\left(\mathrm{m}^{2}\right)\end{array}$ & \\
\hline & Intertidal extent & $\begin{array}{l}\text { Total Intertidal area/Area } \\
\text { submerged at MLS }\left(\mathrm{m}^{2}\right)\end{array}$ & $\begin{array}{l}\text { To represent the influence of the } \\
\text { extent of intertidal relative to aquatic } \\
\text { habitat at low tide (proxy for potential } \\
\text { holding capacity of system) }\end{array}$ \\
\hline \multirow[t]{5}{*}{$\begin{array}{l}\text { Mangrove } \\
\text { variables }\end{array}$} & $\begin{array}{l}\text { Mangrove forest } \\
\text { shape }\end{array}$ & $\begin{array}{l}\text { Mangrove area } \\
\left(\mathrm{m}^{2}\right) / \text { Mangrove perimeter } \\
(\mathrm{m})\end{array}$ & $\begin{array}{l}\text { To represent the influence of compact } \\
\text { verses linear shapes }\end{array}$ \\
\hline & Mangrove extent & $\begin{array}{l}\text { Mangrove area }\left(\mathrm{m}^{2}\right) / \text { Area } \\
\text { submerged at } \mathrm{MLS}\left(\mathrm{m}^{2}\right)\end{array}$ & $\begin{array}{l}\text { To represent the influence of the } \\
\text { extent of mangroves relative to aquatic } \\
\text { habitat at low tide }\end{array}$ \\
\hline & $\begin{array}{l}\text { Mangrove-water } \\
\text { interface }\end{array}$ & $\begin{array}{l}\text { Mangrove forest interface } \\
\text { with subtidal }(\mathrm{m}) / \text { Area } \\
\text { submerged at MLS }\left(\mathrm{m}^{2}\right)\end{array}$ & $\begin{array}{l}\text { To represent the influence of the } \\
\text { amount of edge for connectivity with } \\
\text { the mangrove forest relative to aquatic } \\
\text { habitat at low tide }\end{array}$ \\
\hline & Mangrove edge extent & $\begin{array}{l}\text { Mangrove forest interface } \\
\text { with subtidal }(\mathrm{m}) / \text { Total } \\
\text { intertidal perimeter }(\mathrm{m})\end{array}$ & $\begin{array}{l}\text { To represent the influence of the } \\
\text { proportion of the system edge } \\
\text { providing connectivity with the } \\
\text { mangrove forest }\end{array}$ \\
\hline & $\begin{array}{l}\text { Mangrove forest } \\
\text { access }\end{array}$ & $\begin{array}{l}\text { Mangrove forest interface } \\
\text { with subtidal }(\mathrm{m}) / \text { Mangrove } \\
\text { area }\left(\mathrm{m}^{2}\right)\end{array}$ & $\begin{array}{l}\text { To represent the influence of the } \\
\text { extent of access relative the size of the } \\
\text { mangrove forest }\end{array}$ \\
\hline \multirow[t]{5}{*}{$\begin{array}{l}\text { Impact } \\
\text { variables }\end{array}$} & $\begin{array}{l}\text { Total anthropogenic } \\
\text { development }\end{array}$ & $\begin{array}{l}\text { Total \% of perimeter } \\
\text { developed }\end{array}$ & $\begin{array}{l}\text { Measure of the total extent of } \\
\text { development around the system }\end{array}$ \\
\hline & $\begin{array}{l}\text { Urban/industrial } \\
\text { proportion }\end{array}$ & $\begin{array}{l}\text { \% perimeter with adjacent } \\
\text { urban or industrial } \\
\text { development }\end{array}$ & $\begin{array}{l}\text { Measure of the extent of } \\
\text { urban/industrial development around } \\
\text { the system }\end{array}$ \\
\hline & $\begin{array}{l}\text { Aquaculture } \\
\text { proportion }\end{array}$ & $\begin{array}{l}\% \text { perimeter with adjacent } \\
\text { aquaculture }\end{array}$ & $\begin{array}{l}\text { Measure of the extent of aquaculture } \\
\text { development around the system }\end{array}$ \\
\hline & Agriculture proportion & $\begin{array}{l}\text { \% perimeter with adjacent } \\
\text { agriculture }\end{array}$ & $\begin{array}{l}\text { Measure of the extent of agricultural } \\
\text { development around the system }\end{array}$ \\
\hline & Pasture proportion & $\begin{array}{l}\text { \%perimeter with adjacent } \\
\text { pasture }\end{array}$ & $\begin{array}{l}\text { Measure of the extent of pastoral } \\
\text { development around the system }\end{array}$ \\
\hline
\end{tabular}


Table 2: Spatial explanatory variables and variables collected for each net in the "within-estuaries" analysis

\begin{tabular}{|c|c|c|c|}
\hline & Name & Description & Purpose \\
\hline \multirow[t]{3}{*}{$\begin{array}{l}\text { Spatial } \\
\text { variables }\end{array}$} & Trip & $\begin{array}{l}\text { March, April, May, July, September, October, } \\
\text { November, December 2008, January } 2009\end{array}$ & \multirow{3}{*}{$\begin{array}{l}\text { Allow assessment of temporal and } \\
\text { spatial change at the estuary-to- } \\
\text { estuary level }\end{array}$} \\
\hline & Estuary & $\begin{array}{l}\text { Insulator, Bluewater, Healy, Sandfly, Cocoa, } \\
\text { Doughboy, Crab, Mud, Hell Hole Cks }\end{array}$ & \\
\hline & Reach & $\begin{array}{l}\text { Downstream (all estuaries), Mid (all except } \\
\text { Bluewater \& Healy), Upstream (all except } \\
\text { Bluewater) }\end{array}$ & \\
\hline \multirow[t]{8}{*}{$\begin{array}{l}\text { Net-level } \\
\text { variables }\end{array}$} & Substrate & $\begin{array}{l}\text { mud ( }>75 \% \text { mud sized particles), mud_s ( } 75- \\
50 \% \text { mud sized particles), sand_m ( } 50-25 \% \text { mud } \\
\text { sized particles), sand ( }<25 \% \text { mud sized } \\
\text { particles) }\end{array}$ & $\begin{array}{l}\text { To represent the influence of } \\
\text { substrate type }\end{array}$ \\
\hline & Hydrodynamics & $\begin{array}{l}\text { eddy, pressure point, still water, low current } \\
\text { flow, moderate flow, high flow }\end{array}$ & $\begin{array}{l}\text { To represent the influence of } \\
\text { hydrodynamics }\end{array}$ \\
\hline & Bank angle & $\begin{array}{l}\text { mean of } 3 \text { measurements; top of bank, waters } \\
\text { edge, half way between }\end{array}$ & $\begin{array}{l}\text { A proxy for the extent of shallow } \\
\text { water throughout the tide }\end{array}$ \\
\hline & Canopy overhang & $\begin{array}{l}\text { presence or absence of overhanging canopy at } \\
\text { sampling site }\end{array}$ & $\begin{array}{l}\text { To represent the influence of } \\
\text { vegetation shading }\end{array}$ \\
\hline & Structure & $\begin{array}{l}\text { presence or absence of roots or other timber at } \\
\text { the perimeter of the sampling site }\end{array}$ & $\begin{array}{l}\text { To represent the influence of } \\
\text { complex structure }\end{array}$ \\
\hline & $\begin{array}{l}\text { Dominant cover } \\
\text { mix }\end{array}$ & $\begin{array}{l}\text { bare, mangrove single species (named), mixed } \\
\text { mangroves, salt marsh/mangroves, salt couch } \\
\text { (Sporobolus virginicus), salt marsh succulents, } \\
\text { terrestrial vegetation }\end{array}$ & $\begin{array}{l}\text { To represent the influence of } \\
\text { vegetation type }\end{array}$ \\
\hline & $\begin{array}{l}\text { Mangrove } \\
\text { pres/abs }\end{array}$ & presence or absence of mangroves & \multirow{2}{*}{$\begin{array}{l}\text { Two approaches to representing the } \\
\text { influence of the occurrence of } \\
\text { mangroves }\end{array}$} \\
\hline & $\begin{array}{l}\text { Mangrove } \\
\text { dominant }\end{array}$ & mangroves dominant plant or not & \\
\hline
\end{tabular}

Table 3: Percentage of months in which main factors had high explanatory power in CART for "within-estuaries" analysis:

\begin{tabular}{|r|c|c|c|}
\hline & 1st split & any split & surrogate $\mathbf{5 0 \%}$ \\
\hline location & 78 & 89 & 100 \\
\hline bank angle & 22 & 89 & $\mathbf{7 8}$ \\
\hline dominant veg & 0 & 56 & 44 \\
\hline Reach & 0 & 11 & 56 \\
\hline Substrate & 0 & 44 & 33 \\
\hline Hydrodynamics & 0 & 11 & 11 \\
\hline mangrove dominance & 0 & 0 & 0 \\
\hline
\end{tabular}




\section{References}

Abrantes K, Sheaves M (2008) Incorporation of terrestrial wetland material into aquatic food webs in a tropical estuarine wetland. Estuarine, Coastal and Shelf Science 80:401-412

Abrantes K, Sheaves M (2009a) Food web structure in a near-pristine mangrove area of the Australian Wet Tropics. Estuarine Coastal and Shelf Science 82:597-607

Abrantes K, Sheaves M (2009b) Sources of nutrition supporting juvenile penaeid prawns in an Australian dry tropics estuary. Marine and Freshwater Research 60:949-959

Abrantes K, Sheaves M (2009c) Sources of nutrition supporting juvenile penaeid prawns in an Australian Dry Tropics estuary. Marine and Freshwater Research 60:949-959

Abrantes K, Sheaves M (2010) Importance of freshwater flow in terrestrial-aquatic energetic conectivity in intermittently connected estuaries of tropical Australia. Marine Biology 157:2071-2086

Ahmad Adnan N, Loneragan NR, Connolly RM (2002) Variability of, and the influence of environmental factors on, the recruitment of postlarval and juvenile Penaeus merguiensis in the Matang mangroves of Malaysia. Marine Biology 141:241-251

Baker R, Sheaves M (2006) Visual surveys reveal high densities of large piscivores in shallow estuarine nurseries. Marine Ecology Progress Series 323: 75-82

Baker R, Sheaves M (2009) Overlooked small and juvenile piscivores dominate shallow-water estuarine "refuges" in tropical Australia. Estuarine, Coastal and Shelf Science 85: 618-626

Barbier E, Strand I (1997) Valuing mangrove-fishery linkages: a case study of Campeche, Mexico 8th Annual Conference of European Assocciation of Envorinmental and Resoruce Economics. EAERE, Tilburg University, The Netherlands, $p 27$

Blaber SJM (1980) Fish of the Trinity Inlet system of north Queensland with notes on the eology of fish faunas of tropical Indo-Pacific estuaries. Aust J Mar Freshwater Res 31:137-146

Bouillon S, Connolly RM, Lee SY (2008) Organic matter exchange and cycling in mangrove ecosystems: Recent insights from stable isotope studies. Journal of Sea Research 59:44-58

Bouillon S, Dehairs F, Velimirov B, Abril G, Borges AV (2007) Dynamics of organic and inorganic carbon across contiguous mangrove and seagrass systems (Gazi Bay, Kenya). J Geophys Res 112:G02018

Breiman L, Friedman J, Olshen R, Stone C (1984) Classification and regression trees, Vol. Wadsworth Internation Group, Belmont

Chong VC, Low CB, Ichikawa T (2001) Contribution of mangrove detritus to juvenile prawn nutrition: a dual stable isotope study in a Malaysian mangrove forest. Marine Biology 138:77-86

Coles RG, Lee Long WJ, Watson RA, Derbyshire KJ (1993) Distribution of seagrasses, and their fish and penaeid prawn communities, in Cairns harbour, a tropical estuary, Northern Queensland, Australia. Australian journal of marine and freshwater research 44:193-210

Crocos PJ, Kerr JD (1983) Maturation and spawinging of the banana prawn Penaeus merguiesis DeMan (Crustacea, Penaeidae) in the Gulf of Carpentaria, Australia. Journal of Experimental Marine Biology and Ecology 69:37-59

Dall W, Hill BJ, Rothlisberg PC, Staples DJ (1990) The biology of the Penaeidae. Advances in Marine Biology 27:1-461

Dalzell P, Adams TJH, Polunin NVC (1996) Coastal fisheries in the Pacific islands. In: Oceanography and Marine Biology, Vol 34, Vol 34, p 395-531

De'ath G, Fabricius KE (2000) Classification and regression trees: A powerful yet simple technique for ecological data analysis. Ecology 81:3178-3192

de Graaf GJ, Xuan TT (1998) Extensive shrimp farming, mangrove clearance and marine fisheries in the southern provinces of Vietnam. Mangroves and Salt Marshes [Mangroves Salt Marshes] 2:159-166

Duke N (1992) Mangrove floristics and biogeography. In: Robertson A, Blaber S (eds) Tropical Mangrove Ecosystems. Americal Geophysical Union, Washington, DC, p 63-100 
Gedan KB, Kirwan ML, Wolanski E, Barbier EB, Silliman BR (2011) The present and future role of coastal wetland vegetation in protecting shorelines: answering recent challenges to the paradigm. Climatic Change 106:7-29

Hamid MN, Perry JN, Powell W, Rennolls K (1999) The effect of spatial scale on interactions between two weevils and their food plant. Acta Oecologica 20:537-549

Holling CS (1992) Cross-Scale Morphology, Geometry, and Dynamics of Ecosystems. Ecological Monographs 62:447-502

Holthuis L (1980) FAO species catalogue. Vol. 1. Shrimps and prawns of the world. FAO Fisheries Synopsis. Food \& Agriculture Organisation of the United Nations, Rome

Johnston R, Sheaves M (2007) Small fish and crustaceans demonstrate a preference for particular small-scale habitats when mangrove forests are not accessible. Journal of Experimental Marine Biology and Ecology 353: :164-179

Johnston R, Sheaves M (2008) Cross-channel distribution of small fish in tropical and subtropical coastal wetlands depends on their trophic and taxonomic identities and on wetland depth. Marine Ecology Progress Series 357:255-270

Johnston R, Sheaves M, Molony B (2007) Are distributions of fish in tropical estuaries influenced by turbidity over small spatial scales? J Fish Biol 71:657-671

Karani I, Kitsos MS, Chartosia N, Koukouras A (2005) Diet composition of the penaeid shrimp, Melicertus kerathurus (Forskal, 1775) (Decapoda, Penaeidae) in the Aegean Sea. Crustaceana 78:385-396

Kenyon RA, Loneragan NR, Manson FJ, Vance DJ, Venables W (2004) Allopatric distribution of juvenile red-legged banana prawns (Penaeus indicus $\mathrm{H}$. Milne Edwards, 1837) and juvenile white banana prawns (Penaeus merguiensis De Man, 1888), and inferred extensive migration, in the Joseph Bonaparte Gulf, northwest Australia Journal of Experimental Marine Biology and Ecology 309:79-108

Kieckbusch DK, Koch MS, Serafy JE, Anderson WT (2004) Trophic linkages among primary producers and consumers in fringing mangroves of subtropical lagoons. Bulletin of Marine Science 74:271-285

Lee SY (2004) Relationship between mangrove abundance and tropical prawn production: a reevaluation. Marine Biology 145:943-949

Levin SA (1992) The Problem of Pattern and Scale in Ecology: The Robert H. MacArthur Award Lecture. Ecology 73:1943-1967

Loneragan NR, Adnan NA, Connolly RM, Manson FJ (2005) Prawn landings and their relationship with the extent of mangroves and shallow waters in western peninsular Malaysia. Estuarine Coastal and Shelf Science 63:187-200

Loneragan NR, Bunn SE, Kellaway DM (1997) Are mangroves and seagrasses sources of organic carbon for penaeid prawns in a tropical Australian estuary? A multiple stable-isotope study. Marine Biology 130:289-300

Manson FJ, Loneragan NR, Harch BD, Skilleter GA, Williams L (2005) A broad-scale analysis of links between coastal fisheries production and mangrove extent: A case-study for northeastern Australia. Fish Res 74:69-85

Meynecke JO, Lee SY, Duke NC (2008) Linking spatial metrics and fish catch reveals the importance of coastal wetland connectivity to inshore fisheries in Queensland, Australia. Biological Conservation 141:981-996

Minello TJ, Matthews GA, Caldwell PA, Rozas LP (2008) Population and production estimates for decapod crustaceans in wetlands of Galveston Bay, Texas. Transactions of the American Fisheries Society 137:129-146

Mumby PJ, Edwards AJ, Arias-Gonzalez JE, Lindeman KC, Blackwell PG, Gall A, Gorczynska MI, Harborne AR, Pescod CL, Renken H, Wabnitz CCC, Llewellyn G (2004) Mangroves enhance the biomass of coral reef fish communities in the Caribbean. Nature 427:533-536 
Nagelkerken I (2007) Are non-estuarine mangroves connected to coral reefs through fish migration? Bulletin of Marine Science 80:595-596.597

Paterson AW, Whitfield AK (2000) Do Shallow-water Habitats Function as Refugia for Juvenile Fishes? Estuarine, Coastal and Shelf Science [Estuar Coast Shelf Sci] 51:359-364

Primavera JH (1998) Mangroves as nurseries: Shrimp populations in mangrove and non-mangrove habitats. Estuarine Coastal and Shelf Science 46:457-464

Robertson A, Blaber S (1992) Plankton, epibenthos and fish communities. In: Robertson A, Blaber S (eds) Tropical Mangrove Ecosystems. Americal Geophysical Union, Washington, p 173-224

Robertson Al, Duke NC (1990) Recruitment, growth and residence time of fishes in a tropical Australian mangrove system. Estuar Coast Shelf Sci 31:723-743

Rothlisberg PC, Jackson CJ (1987) Larval ecology of penaeids of the Gulf of Carpentaria, Australia .2. hydrographic environment of Penaeus merguiensis, Penaeus esculentus, Penaeus semisulcatus and Penaeus latisulcatus zoeae. Australian Journal of Marine and Freshwater Research 38:19-28

Rothlisberg PC, Staples DJ, Crocos PJ (1985) A review of the life history of the banana prawn, Penaeus merguiensis, in the Gulf of Carpentaria.

Rozas LP, Minello TJ (1998) Nekton use of salt marsh, seagrass, and nonvegetated habitats in a south Texas (USA) estuary. Bulletin of Marine Science 63:481-501

Salini JP, Brewer DT, Blaber SJM (1998) Dietary studies on the predatory fishes of the Norman River Estuary, with particular reference to penaeid prawns. Estuarine, Coastal and Shelf Science [Estuar Coast Shelf Sci] 46:837-847

Sheaves M (2005) Nature and consequences of biological connectivity in mangrove systems. Marine Ecology Progress Series 302:293-305

Sheaves M (2006) Scale dependent variation in composition of fish fauna among tropical estuarine sandy embayments. Marine Ecology Progress Series 310:173-184

Sheaves M (2009) The Consequences of Ecological Connectivity: the Example of the Coastal Ecosystem Mosaic. Marine Ecology Progress Series 391:107-115

Sheaves M, Abrantes K, Johnston R (2007a) Nursery Ground Value of an Endangered Wetland to Juvenile Shrimps. Wetlands Ecology and Management 15:311-327

Sheaves M, Johnston R (2009) Ecological drivers of spatial variability among fish fauna of 21 tropical Australian estuaries. Marine Ecology Progress Series 385:245-260

Sheaves M, Johnston R (2010) Implications of Spatial Variability of Fish Assemblages for Monitoring of Australia's Tropical Estuaries. . Aquatic Conservation Marine and Freshwater Systems 20:348-356

Sheaves M, Johnston R, Abrantes K (2007b) Fish fauna of dry sub-tropical estuarine floodplain wetlands Marine and Freshwater Research 58:931-943

Sheaves M, Johnston R, Connolly R (2010) Temporal Dynamics of Fish Assemblages of Natural and Artificial Tropical Estuaries. Marine Ecology Progress Series 410:143-157

Staples D, Vance DJ, Heales DS (1985) Habitat requirements of juvenile penaeid prawns and their relationship to offshore fisheries. . In: P R (ed) Second Australian National Prawn Seminar. CSIRO, Kooralbyn, Queensland, p 47-54

Staples DJ (1979) Seasonal migration patterns of post-larval and juvenile banana prawns, Penaeus merguiensis De Man, in the major rivers of the Gulf of Carpentaria, Australia. Australian Journal of Marine and Freshwater Research 30:143-157

Staples DJ, Vance DJ (1985) Short-term and long-term influences on the immigration of postlarval banana prawns Penaeus merguiensis, into a mangrove estuary of the Gulf of Carpentaria, Australia. Marine ecology progress series Oldendorf 23:15-29

Staples DJ, Vance DJ (1986) Emigration of juvenile banana prawns Penaeus merguiensis from a mangrove estuary and recruitment to offshore areas in the wet-dry tropic of the Gulf of Carpentria, Australia. Marine ecology progress series Oldendorf 27:239-252 
Staples DJ, Vance DJ (1987) Comparative recruitment of the banana prawn, Penaeus merguiensis, in five estuaries of the south-eastern Gulf of Carpentaria, Australia. Aust J Mar Freshwat Res 38:29-45

Staples DJ, Vance DJ, Loneragan NR (1995) Penaeid prawn recruitment variability: Effect of the environment. Conf Workshop Ser Dep Primary Ind

Subramaniam SP (1990) Chawaka Bay (Zanzibar, East-Africa) as a nursery ground for penaeid prawns. Hydrobiologia 208:111-122

Vance DJ, Haywood MDE, Heales DS, Kenyon RA, Loneragan NR (1998) Seasonal and annual variation in abundance of postlarval and juvenile banana prawns Penaeus merguiensis and environmental variation in two estuaries in tropical northeastern Australia: a six year study. Marine Ecology-Progress Series 163:21-36

Vance DJ, Haywood MDE, Heales DS, Kenyon RA, Loneragan NR, Pendrey RC (1996) How far do prawns and fish move into mangroves? Distribution of juvenile banana prawns Penaeus merguiensis and fish in a tropical mangrove forest in northern Australia. Marine EcologyProgress Series 131:115-124

Vance DJ, Haywood MDE, Heales DS, Kenyon RA, Loneragan NR, Pendrey RC (2002) Distribution of juvenile penaeid prawns in mangrove forests in a tropical Australian estuary, with particular reference to Penaeus merguiensis. Marine Ecology-Progress Series 228:165-177

Vance DJ, Haywood MDE, Staples DJ (1990) Use of a mangrove estuary as a nursery area by postlarval and juvenile banana prawns, Penaeus merguiensis de Man, in northern Australia. Estuarine, Coastal and Shelf Science 31:689-701

Zimmerman RJ, Minello TJ, Rozas LP (2000) Salt marsh linkages to productivity of penaeid shrimps and blue crabs in the northern Gulf of Mexico, Vol 
Figure 1

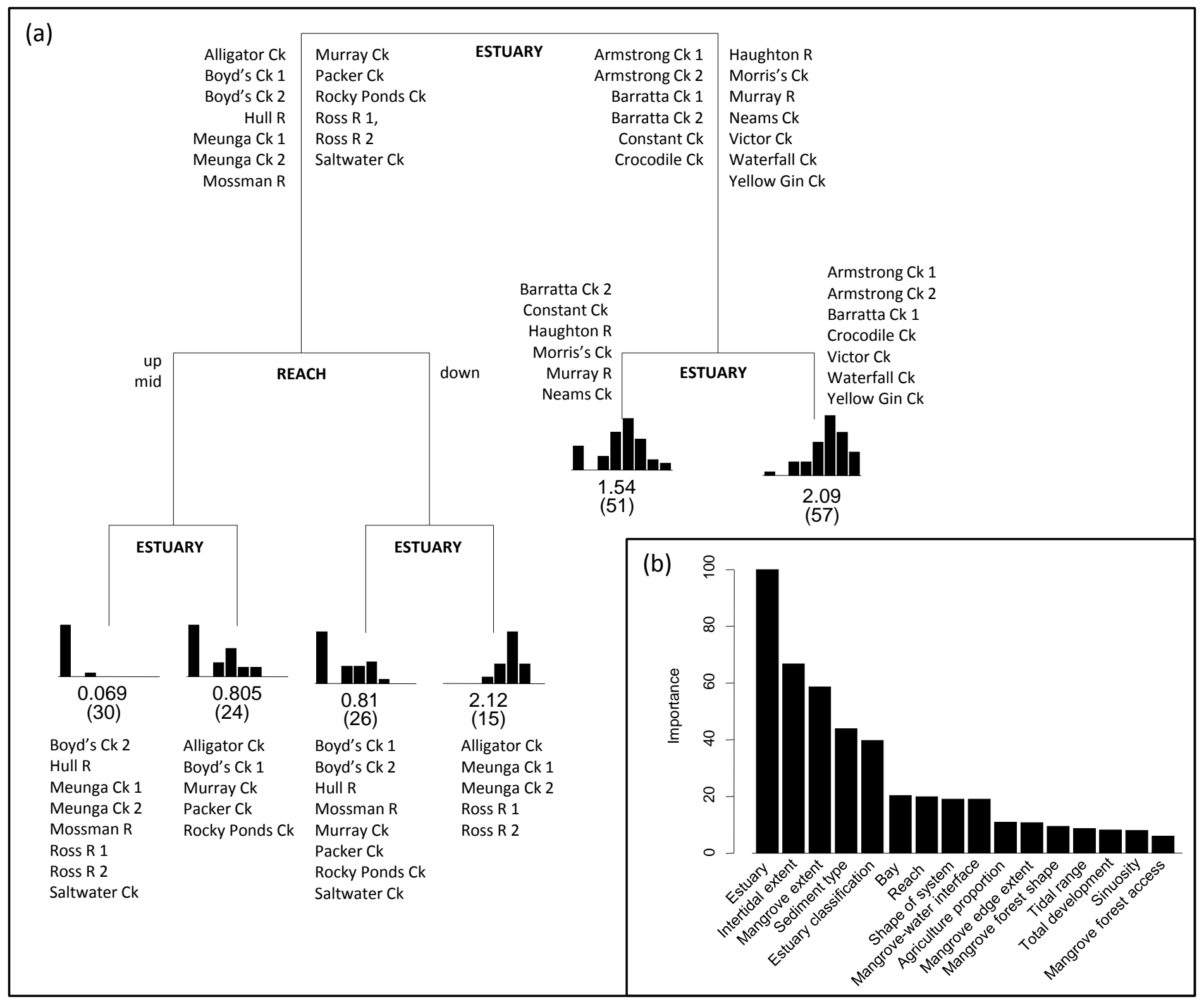


Figure 2

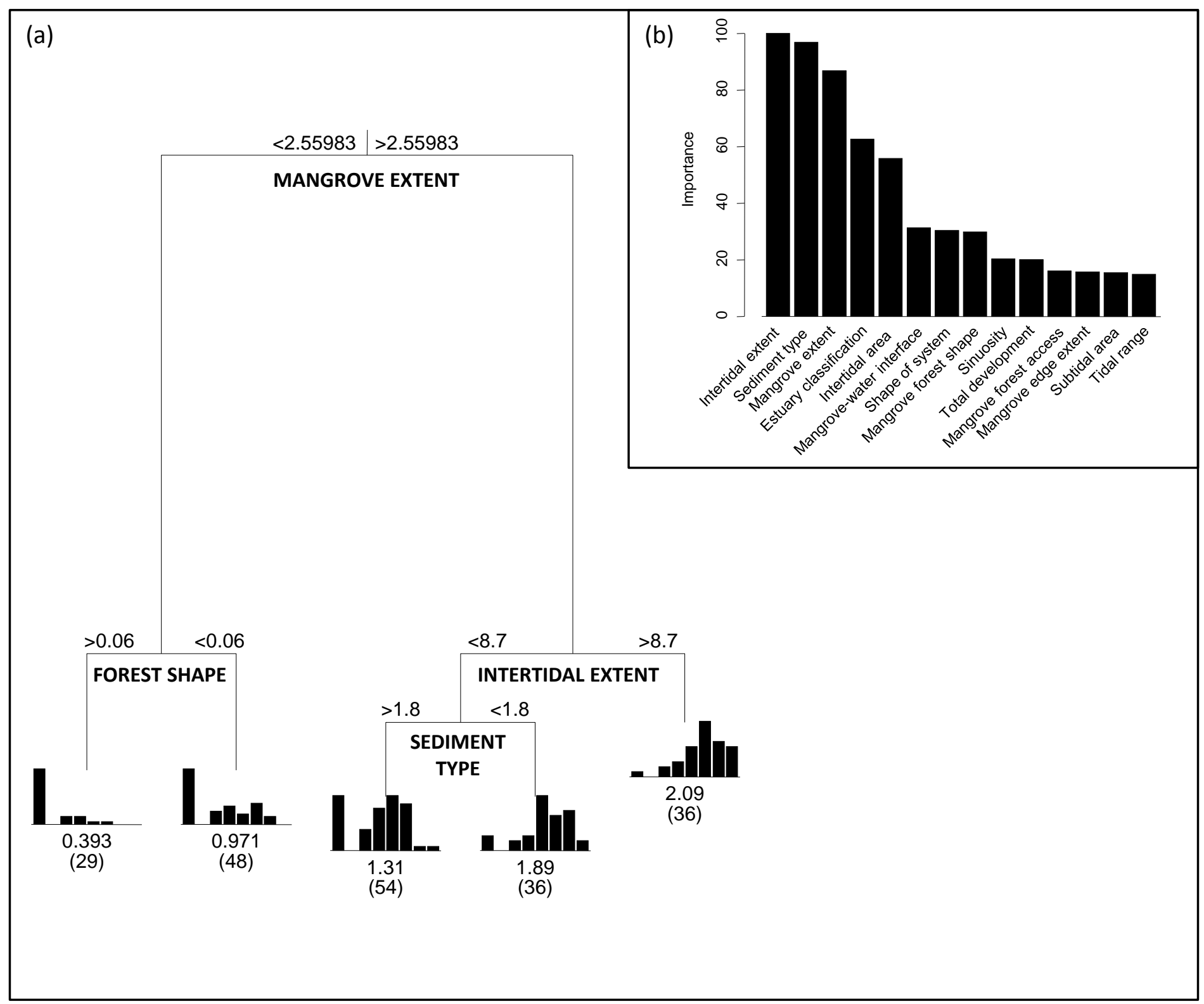


Figure 3
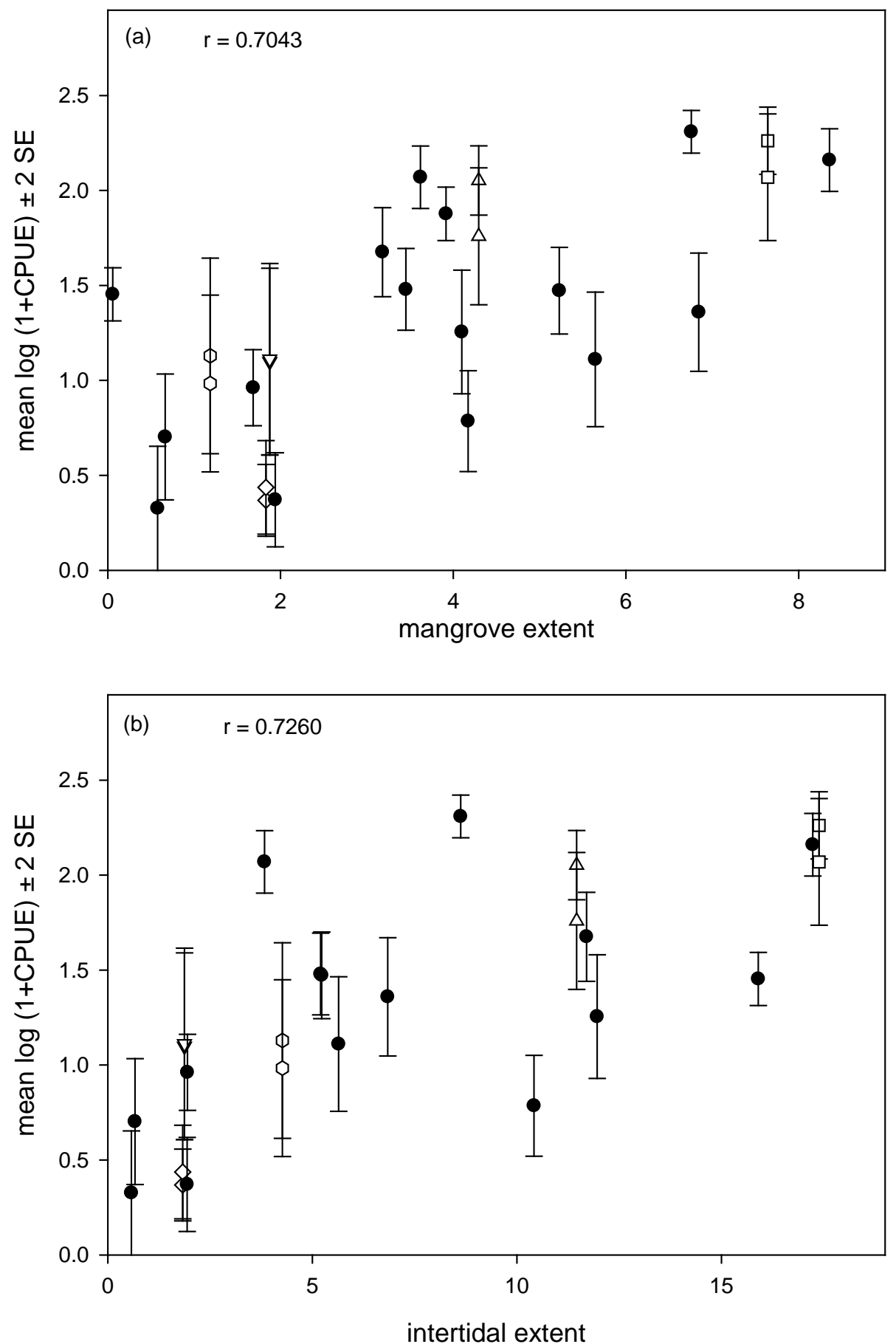
Figure 4

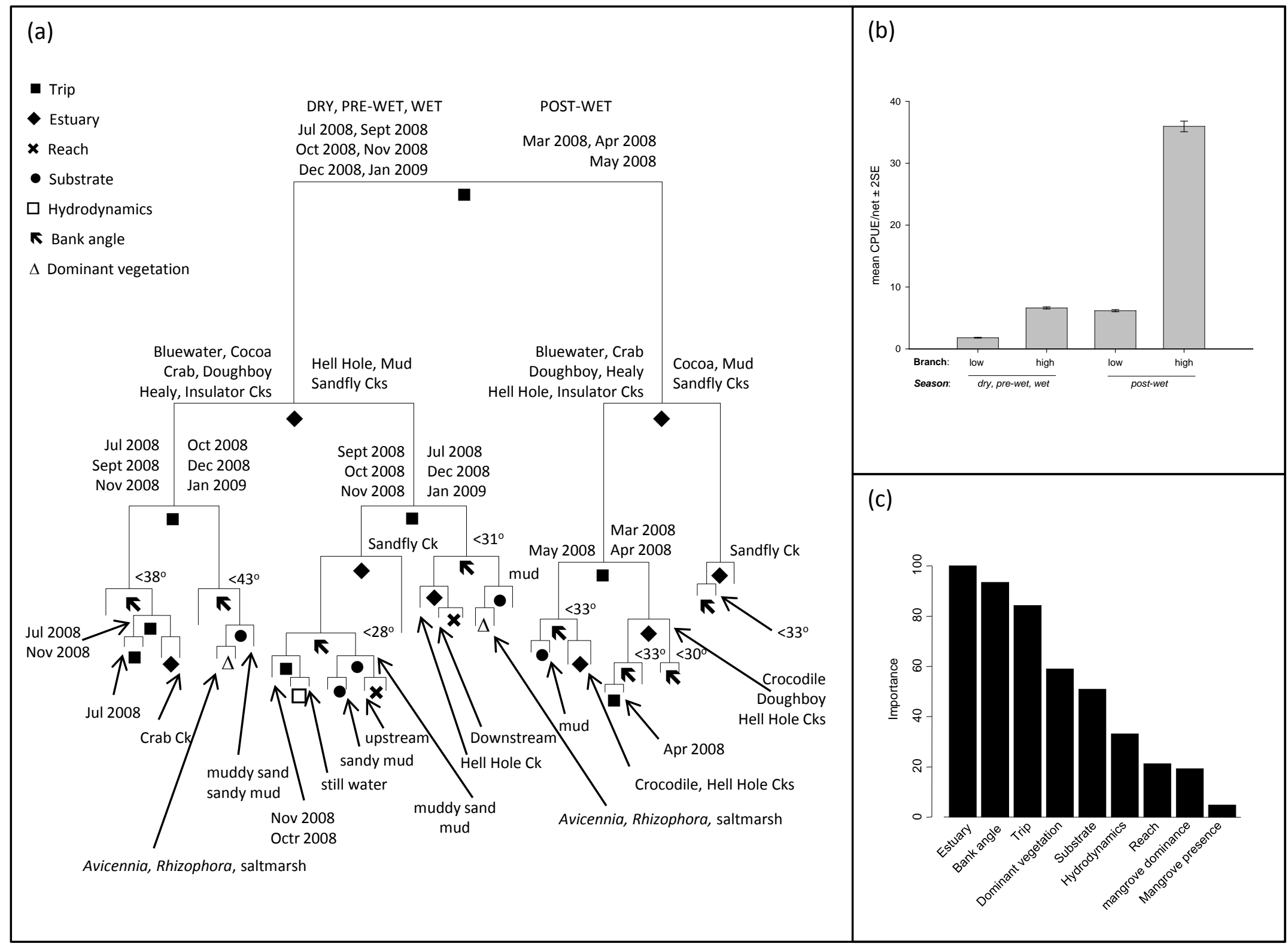


Figure 5

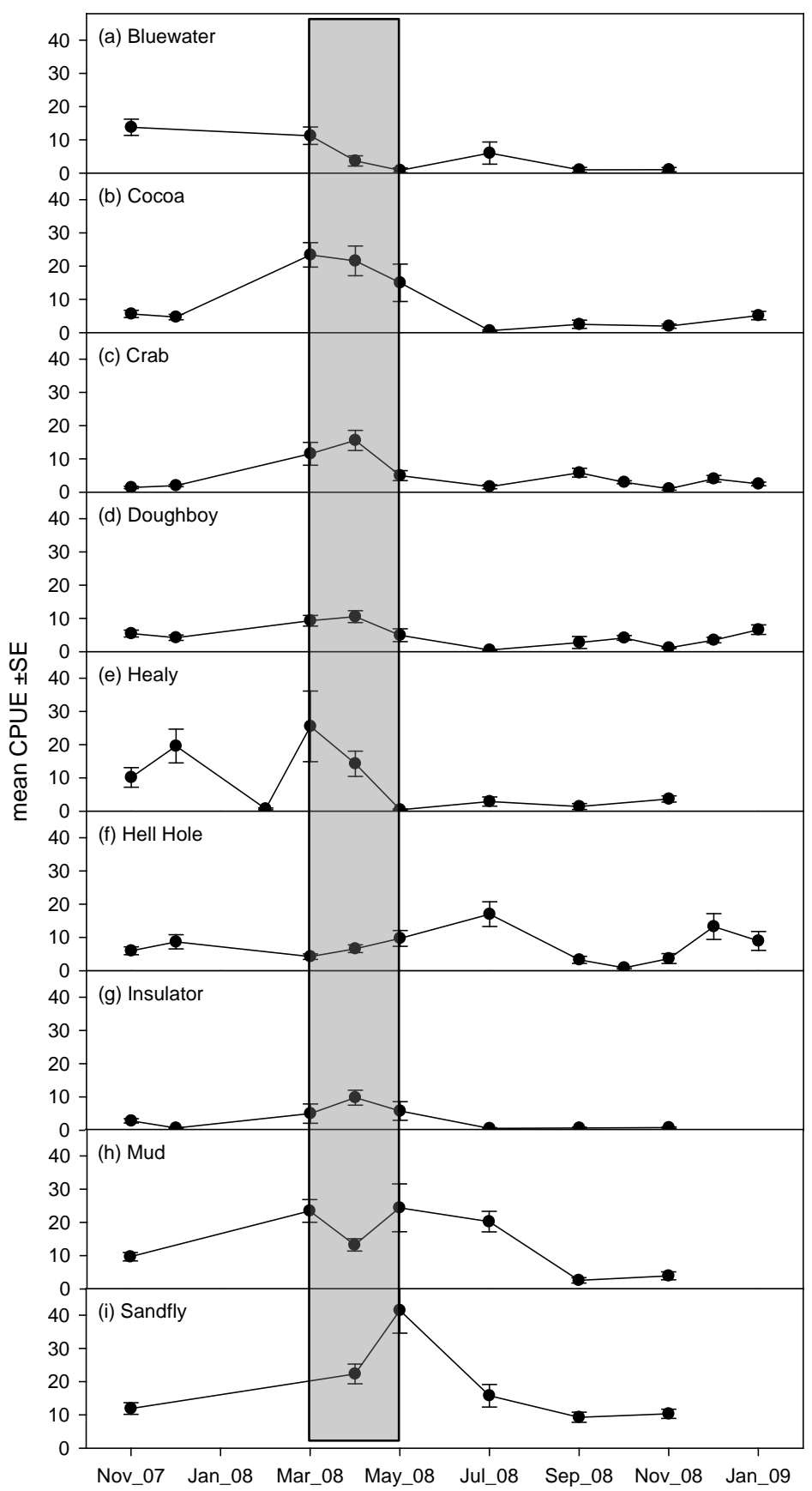


Figure 6

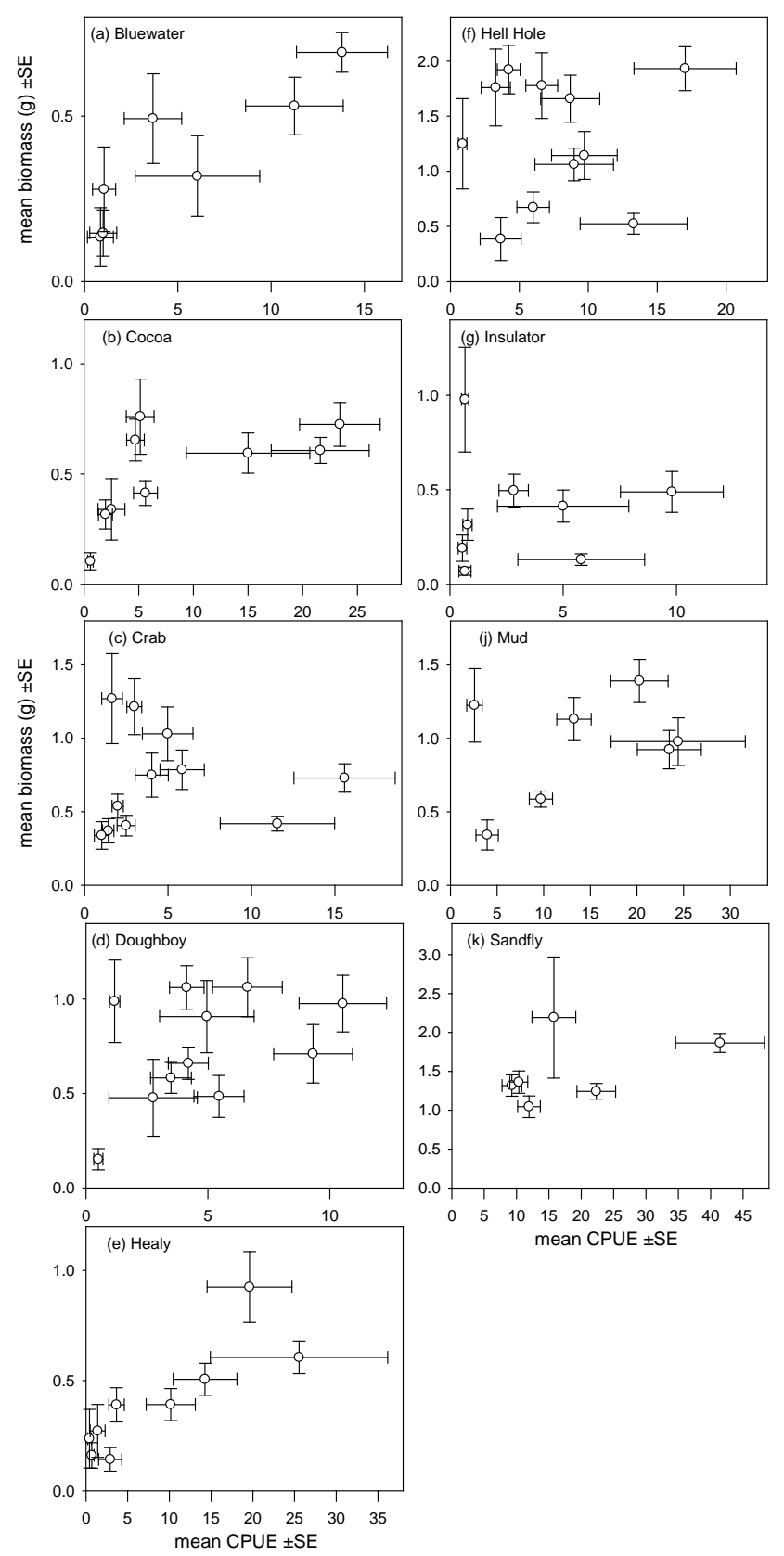

